\title{
Historical-Constructive Analysis of the Lighthouse of Santa Clara Island (San Sebastian, Spain)
}

\author{
Santiago Sánchez-Beitia ${ }^{1}$, Daniel Luengas-Carreño ${ }^{1 *}$, Maite Crespo de Antonio $^{2}$ \\ ${ }^{1}$ High Technical School of Architecture, University of the Basque Country UPV/EHU, 20018 Plaza Oñati 2, Donostia - San \\ Sebastián, Spain \\ ${ }^{2}$ Basque Government Education, Xalbador Bertsolaria 9, 20018 Donostia - San Sebastián, Spain
}

Corresponding Author Email: daniel.luengas@ehu.eus

https://doi.org/10.18280/ijsdp.150402

Received: 7 January 2020

Accepted: 16 April 2020

\section{Keywords:}

historical-constructive analysis, historical lighthouses, industrial heritage, Santa Clara island, construction history

\begin{abstract}
In mid-19 $9^{\text {th }}$ century more than 4,000 lighthouses were erected in the world, using technology specifically developed for this. In Spain, lighthouses were built as a result of four National Plans designed by the Lighthouse Commission. The lighthouse of Santa Clara Island, located in Donostia-San Sebastian (Spain), was built in 1864 during the first of these plans. As other lighthouses, this building has two parts: the tower, where the technology is placed, and an adjacent building, with the house, stores and offices for the lighthouse keeper. Nowadays the emptying of the lighthouse has started according to a project with tourist purposes. The article aims to draw attention to the current situation of this lighthouse, which will lose a large number of its historical elements. In order to achieve this objective, the current state of the lighthouse has been documented and analysed, before a large part of its architectural, structural and technological heritage elements are destroyed. An exhaustive documentary and constructive study of the building has been carried out, determining three main periods of construction: the original lighthouse, which was erected in 1864; the refurbishment of the late $19^{\text {th }}$ or early $20^{\text {th }}$ century, when a new floor was built; and the minor works carried out during the $20^{\text {th }}$ century. It has also been possible to identify the original construction system and architectural elements of the building. From a constructive-architectural viewpoint, the lighthouse of Santa Clara Island is quite similar to other Spanish lighthouses, such as the lighthouses of Suances, San Vicente de la Barquera, Luarca, Avilés or Tazones, which can be classified within the same typological group. It is expected that the results will contribute to highlight the heritage value of the architectural, structural and technological elements of the historical lighthouses, in order to be considered in future protection strategies.
\end{abstract}

\section{INTRODUCTION}

Lighthouses are a combination of architecture and technology, forming genuine "signalling factories" $[1,2]$. Originally, these buildings had multiple functions: they indicated orographic milestones on the coast, they guided navigation, they emitted acoustic signals in foggy weather, they were able to guide air traffic during the first half of the $20^{\text {th }}$ century or they even acted as defensive watchtowers.

Lighthouses usually had two parts: the tower, where the technology was placed, and an adjacent building, with the house, stores and offices for the lighthouse keeper.

The optics (mainly Fresnel lenses) and their rotation mechanisms could reach up from $2,000 \mathrm{~kg}$ in weight in small lighthouses to $15,000 \mathrm{~kg}$ in the tallest lighthouses. These elements were placed on the cusp of a tower several metres high and located in practically inaccessible places, forming genuine construction feats. The optics rotation or obscuration screen mechanism was generated by a weight that fell by force of gravity through the tower. The light generated by the lamp was guided by means of some metal plates that worked by reflection (catoptric optics) or by means of Fresnel lenses (dioptric optics), working by refraction or by means of a combination of both technologies (catadioptric optics). The aim was to generate a beam of light at regular time intervals that unmistakably identifies each lighthouse along the coast [3].

In the adjacent living quarters, the distribution of spaces and their organisation responded to a necessary plan. The lighthouse keeper had to write every day in the Order Log, the Communications Log and the Service Log, mentioning any contingencies observed and even a brief weather report. These professionals had to permanently live in the lighthouse accompanied by their families, creating a peculiar building organisation. Operating the lighthouse required a small office, some small workshops to carry out maintenance and repairs, and stores for fuel and spare parts. They also used to have a cistern, a orchard and premises to stable subsistence animals.

In mid- $19^{\text {th }}$ century more than 4,000 lighthouses were constructed worldwide, using the technology specifically developed for this [4-10]. In Spain, lighthouses were erected as a result of four National Plans designed by the Lighthouse Commission in 1842, 1902, 1967 and 1989/1995. In the first plan, approximately 100 out of the 190 lighthouses in operation today were built [11]

Nowadays, due to current technological advances, 
lighthouses have lost part of the functions assigned to them. For this reason, a large number of projects are being developed today to include tourist uses in the lighthouses. However, it has been detected that most of these projects eliminate a wide range of tangible and intangible valuable elements, causing the distortion of their value as Industrial Heritage [12]. For this reason, in 2017, it was developed the Catalogue of Spanish lighthouses with Heritage Value, for the Institute of Cultural Heritage of Spain [13]. In total, 130 lighthouses were catalogued, which were classified in different typologies [14], according to their volumetry, technology and spatial distribution (Figure 1).

As an example of the Spanish lighthouses, the characteristics of the lighthouse of Santa Clara Island were analysed (Figure 2), which has undergone several transformations since its original construction. This building is located on an island, at the entrance to La Concha Bay in San Sebastian, in the north of the Basque Country. It indicates the position of the only navigable entrance to the port of San Sebastian. In comparison with other lighthouses (e.g., Chipiona, Cape Palos, Tower of Hercules and Maspalomas), it is small in size. The building has two parts: a small tower, which contains the lamp and the optics, and a two-floor adjacent house, with a flat roof. Both structures were built in a neoregionalist style, with large decorative cornices and half point arch doors and windows.

\begin{tabular}{|c|c|c|c|c|}
\hline \multicolumn{3}{|c|}{$\begin{array}{l}\text { Most common compositional typologies } \\
\text { These typologics cover 93\% of the lighthouses with } \\
\text { heritage value }\end{array}$} & $\begin{array}{c}\text { Quantity } \\
\text { of the } \\
\text { subtype }\end{array}$ & $\begin{array}{c}\text { Total number } \\
\text { of lightlouuses by } \\
\text { typology }\end{array}$ \\
\hline \multirow{2}{*}{$\begin{array}{c}\text { Typology A. } \\
\text { Rectangular or } \\
\text { square footprint } \\
\text { with central tower }\end{array}$} & $\begin{array}{l}\text { Subtype A-1. } \\
\text { Tower in } \\
\text { central } \\
\text { courtyard }\end{array}$ & 吕 & 9 & \multirow{2}{*}{29} \\
\hline & $\begin{array}{l}\text { Subtype A-2 } \\
\text { lower in } \\
\text { distributor }\end{array}$ & & 20 & \\
\hline \multirow{2}{*}{$\begin{array}{c}\text { Typology B. } \\
\text { Rectangular or } \\
\text { square footprint } \\
\text { with tower in the } \\
\text { centre of one side }\end{array}$} & $\begin{array}{l}\text { Subtype B-1. } \\
\text { Central } \\
\text { courtyard }\end{array}$ & & 35 & \multirow{2}{*}{65} \\
\hline & $\begin{array}{l}\text { Subtype B-2. } \\
\text { Central } \\
\text { corridor }\end{array}$ & & 30 & \\
\hline $\begin{array}{l}\text { Typology C. } \\
\text { U formed } \\
\text { footprint with } \\
\text { open courtyard }\end{array}$ & - & & - & 11 \\
\hline \multirow{3}{*}{$\begin{array}{c}\text { Typology D. } \\
\text { Other Typologies }\end{array}$} & $\begin{array}{l}\text { Subtype D-1. } \\
\text { Tower and } \\
\text { building } \\
\text { separated and } \\
\text { connected by } \\
\text { a conidor }\end{array}$ & & 6 & \multirow{3}{*}{15} \\
\hline & $\begin{array}{l}\text { Subtype D-2. } \\
\text { Circular } \\
\text { footprint }\end{array}$ & & 6 & \\
\hline & $\begin{array}{l}\text { Subtype D-3. } \\
\text { Semicircular } \\
\text { footprint with } \\
\text { a rectangular } \\
\text { hall }\end{array}$ & & 3 & \\
\hline Unclassified (SC) & \multicolumn{2}{|c|}{-} & - & 10 \\
\hline \multicolumn{3}{|c|}{ TOTAL } & \multicolumn{2}{|c|}{130} \\
\hline
\end{tabular}

Figure 1. Catalogue of Spanish lighthouses with Heritage Value 
As with other lighthouses, these days there is a project to refurbish the lighthouse for tourist purposes. The project is promoted by the City Council of San Sebastian, which aims to empty the building to place a sculpture inside. In this sense, the article also aims to draw attention to the situation of this lighthouse, which will lose a large number of its historical elements. For this purpose, an exhaustive documentary and constructive study of the building has been carried out, determining the different historical phases and the original construction system and architectural elements.

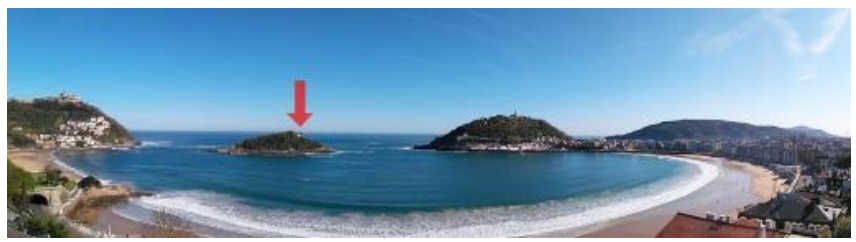

(a) General view of the bay

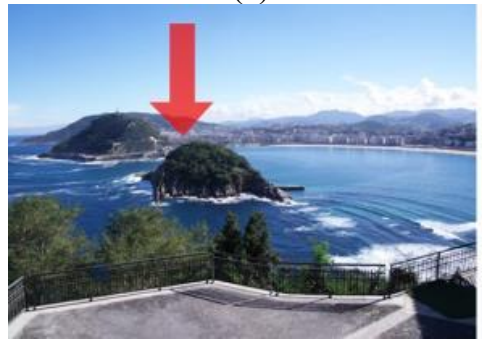

(b) Santa Clara Island

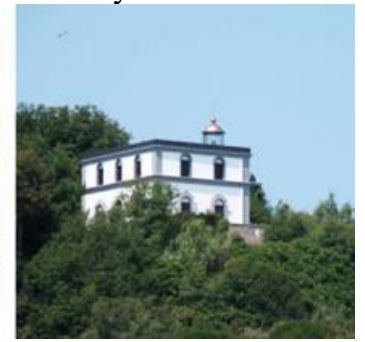

(c) The lighthouse
Figure 2. Different views of La Concha bay, the island in the middle and the lighthouse of Santa Clara Island

\section{METHODOLOGY}

Different international regulations and guidelines were used to establish the heritage value of this lighthouse; such as the National Plan for Industrial Heritage [15, 16]; Recommendation of the Council of Europe R87 24 [17] and R90 20 [18]; the Nizhny Tagil Charter for Industrial Heritage [19]; Principles of Dublin drafted jointly by ICOMOSUNESCO [20]; and Resolution 1924 of the Council of Europe entitled Industrial Heritage in Europe [21].

In order to determine its original elements, the lighthouse of Santa Clara Island was analysed through three complementary sections: the field work, the documentary research and the analysis of the historical-constructive evolution.

In the historical-documentary analysis, most of the documents were obtained from the Historical Archive of Ports of the State. Other archives were also consulted, such as the Archive of the Port Authority of Pasajes, the Municipal Archive of San Sebastian, the Historical Provincial Archive of Gipuzkoa and the National Historical Archive of Spain. Historical photographs and engravings were obtained in the following digital repositories: Basque Digital Library, Donostia-San Sebastián Postcard Collection of GureGipuzkoa repository, IPCE Photo Library, Digital Periodical Library and EMD repository.

In the historical-constructive analysis, a detailed study of the walls was performed indicating different materials, building periods and alterations. The study of the drawings of the original project (Figures 3-4) was essential, which were compared with the current state of the building.

Through these studies, it was possible to determine the original construction system and the architectural, structural and technological elements of the lighthouse of Santa Clara Island. Finally, the characteristics of the original building were compared with those of other lighthouses located on the Cantabrian coast.
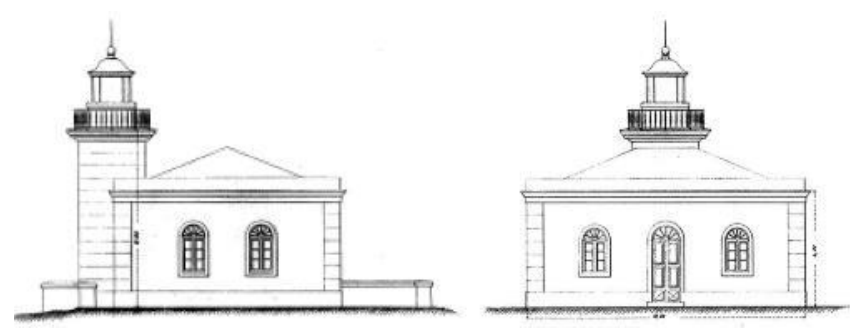

Figure 3. Elevation of the façades in the original project
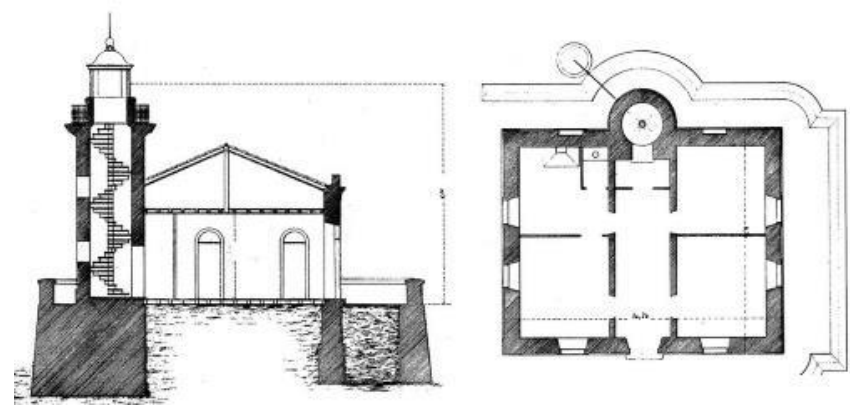

Figure 4. Longitudinal section and ground in the original project

\section{RESULTS AND DISCUSSION}

Three main periods have been detected: the original lighthouse, which was erected in 1864; the refurbishment of the late $19^{\text {th }}$ or early $20^{\text {th }}$ century, when a new floor was built; and the minor works carried out during the $20^{\text {th }}$ century.

\subsection{Phase 1: The original lighthouse}

The lighthouse of Santa Clara Island was erected as a result of the first National Plan promoted by the Lighthouse Commission. According to historical documentation, the first stage of the project began in 1860, when the study of the site was requested [22]. The lighthouse was finally built in 1864, at the highest point of the island, next to the remains of the ancient hermitage of Santa Clara. The project was carried out by the engineer Manuel Estibaus, who also designed the lighthouse of Getaria, which was raised in 1863.

Several reports of this period detailed some characteristics of the original construction and the technology used. According to drawings made in 1867 [23], the original lighthouse was composed of two parts: the lighting tower and an adjacent building. The tower, which still stands, was erected on circular plan, semi-embedded on the centre of north-facing façade (Figure 3). It has a height of $8.50 \mathrm{~m}$ above the ground level and $53 \mathrm{~m}$ above the mean sea level. The adjacent building was planned on one single floor, $4.25 \mathrm{~m}$ high, with a hipped roof and rectangular ground plan of $10.70 \times 8.70$ $\mathrm{m}^{2}$.

According to the documents [24-26], the ashlars of the tower were made of compact blue limestone from the nearby quarries of Astigarribia (Mutriku). The area of the lamp and the dome were painted white and the uprights were painted 
green. From the lighting viewpoint, a sixth order catadioptric optic and a Maris lamp (H. Lépaute firm) was installed, which emitted a fixed white light.

The spatial distribution and location of the lighthouse corresponded to Typology B-2 according to the classification defined in the Catalogue of Spanish lighthouses with Heritage Value (Figure 1). Lighthouses of Typology B-2 had a corridor in the central part, which served as a communication axis. The living and working rooms of the lighthouse keeper were located on the sides of the corridor, while the access to the tower was at the end of the corridor. The spatial distribution of the lighthouse of Santa Clara Island was extremely simple. It was organised into four rooms, two on each side, separated by an entrance hall that connected the main access floor to the tower staircase. The two rooms to the right (Figure 4) were used as an office and small workshop, while the two on the left were used as living quarters (including kitchen and bathroom).

\subsection{Phase 2: The firts refurbishing}

According to the historical photographs (Figure 5), the lighthouse underwent an important refurbishing in the late $19^{\text {th }}$ or early $20^{\text {th }}$ century, when a new upper floor was built in the adjacent building. Although the project of these works could not be found, the images show a substantial alteration of the structure. The new floor, built on top of the walls of the existing plant, was covered with a flat roof, which is the one that remains today. During this work a new door was opened in the tower, to connect it with the new floor.

The modification to include two storeys and a practicable flat roof simplified the work related to the exterior upkeep and maintenance of the tower. The new floor had three bedrooms and a full bathroom. A water tank was located in the flat roof, which was filled from the cistern using manual operating pumps. Outside, a new access road was also built, to improve the accessibility (Figure 5).
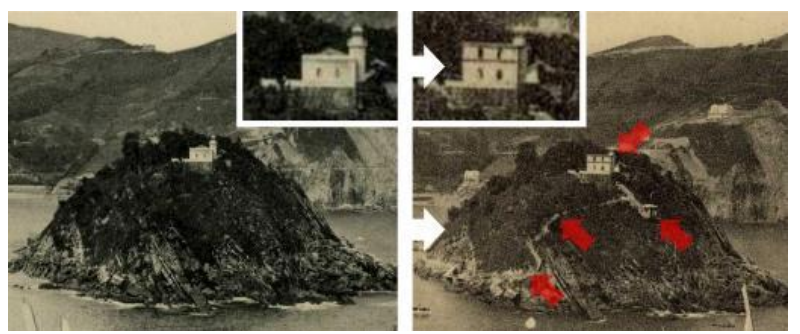

Figure 5. First refurbishing: Second floor and new accesses road. Donostia-San Sebastián Postcard Collection of GureGipuzkoa repository

\subsection{Phase 3: The alterations of the $20^{\text {th }}$ century}

During the first half of the $20^{\text {th }}$ century the lighthouse underwent some minor alterations, which mainly affected the technology of the tower. In 1911, the Lighthouse Commission decided to modify the appearance of the light (Royal Order of 23 February 1911), installing a new white light with groups of three obscuration's that must be achieved with metal screens. The optics remained intact and immobile, coupling a rotation system with two outer screens, with a speed of 1 turn every 30 seconds.

According to the 1911 project (Figure 6), the screens were placed floating in a tank of mercury, connected to a cable and a $30-\mathrm{kg}$ weight that descended by force of gravity down the lighthouse tower ( $8 \mathrm{~m}$ run). The great advance represented by the design of mercury floats in O-ring vats to facilitate the rotation process must be pointed out. This system was ordered in 1911 from the French firm Barbier, Benard and Turenne, increasing the reach of the light to 12 nautical miles $(22.224$ $\mathrm{km})$. The lamp was incandescent powered by gasoline. The complete replacement process ended on 25 August 1916. The long construction and installation period reflect the difficulty of taking any material to the lighthouse. Probably the onset of the First World War in 1914 contributed to the delay of the work.
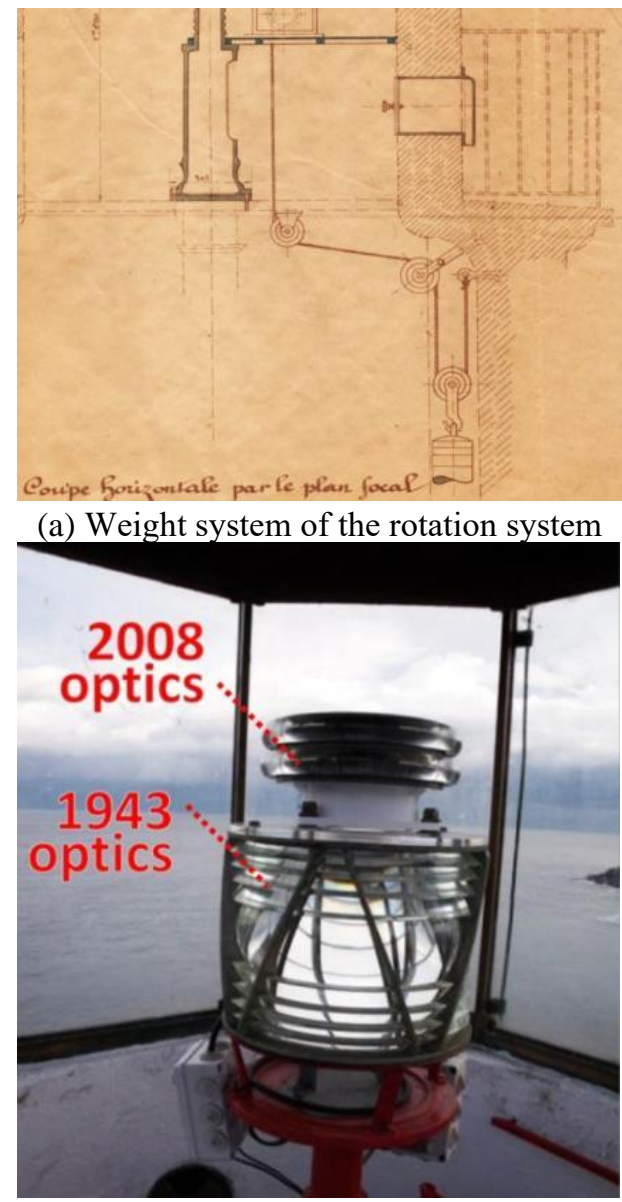

(b) Acrylic optics

Figure 6. (a) Weight system of the rotation system according to the 1911 project; and (b) Acrylic optics of 2008 on whitecoloured and the optics implemented in 1943, with inclined struts

Several decades later, in 1942, the electrification of the lighthouse was carried out. In 1943, the optics was also replaced (Figure 6). This second optics worked with a lamp of compressed acetylene dissolved in acetone. Nowadays, this optics is still kept in the lighthouse as reserve of a new one, which was implemented in 2008. The new optics works with LED lamps, generating flashes with no rotation mechanism.

During this period, the building also underwent some minor alterations. In 1945, the floor planks of the adjacent building were replaced with ceramic tiles (Figure 7) and some repairs were made to the path going from the wharf to the lighthouse. The facades of the building also underwent some modifications in the last decades of the $20^{\text {th }}$ century, opening some windows and installing some sanitation facilities (Figure 7). 


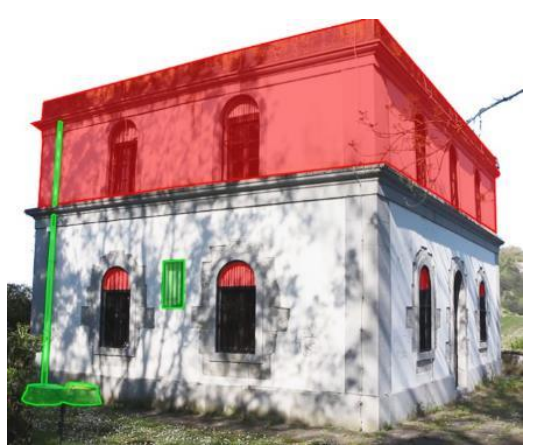

(a) Outside view of the lighthouse

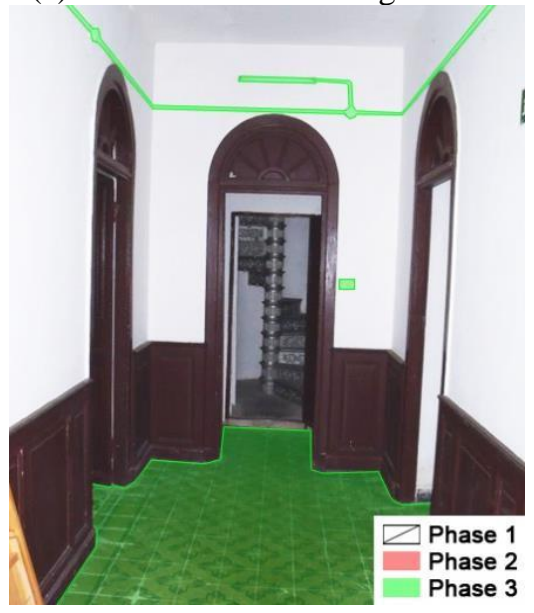

(b) Inside view of the lighthouse

Figure 7. Phases of the lighthouse of Santa Clara Island: (a) Building façades; and (b) Access to the tower from the main entrance hall

\section{THE ORIGINAL CONSTRUCTION SYSTEM AND ELEMENTS}

The historical-constructive study has served to identify and to analyse the original architectural, structural and technological elements of the lighthouse of Santa Clara Island. Following the results of this study and the graphic documentation of 1867 , a virtual reconstruction of the original building has been elaborated (Figure 8). The 3D model was made using AutoCAD. The model was exported to SketchUp in order to manipulate and render it.

The original building had very thick and deep foundation walls, possibly due to the steep slope of the site. The perimeter walls of the building were erected on top of these structures, using mainly limestone masonry. The use of ashlar was reserved for the openings and corners. As mentioned above, the walls of the tower were built with compact blue stone blocks from the quarries of Astigarribia (Mutriku).

The original building had a very simple structural system. The floors of the adjacent building were made with wooden beams. These beams were supported by the inner setbacks of the walls. The building had two interior stone walls, perpendicular to the main façade, on which the attic beams rested. These two walls also had the function of supporting the two posts of the roof, elements on which the ridge beam and the four hip rafters rested. The rafters, planks and tiles of the hipped roof were supported on this structure. The spiral staircase of the tower was sustained by a long circular metal column.

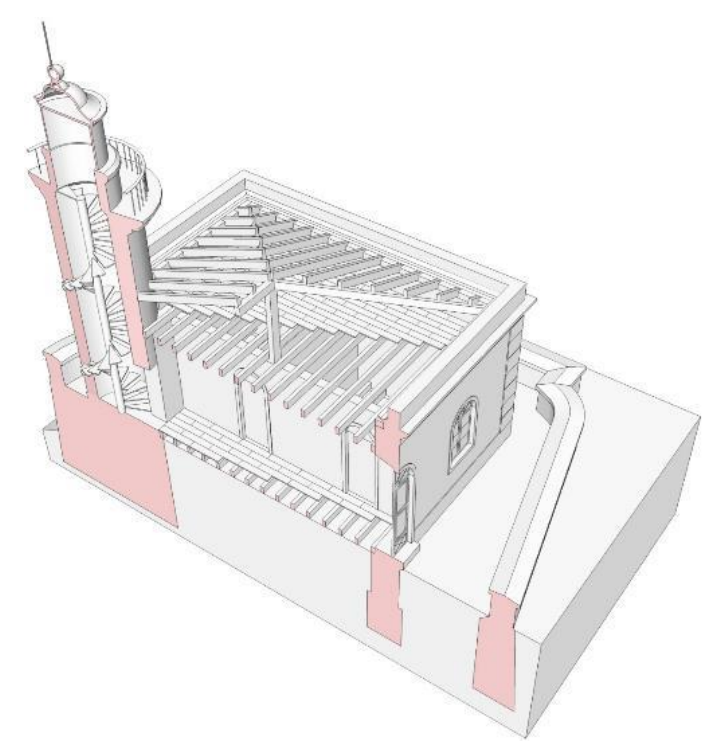

Figure 8. Virtual reconstruction of the original system and structure

The ground floor has reached our days with a similar internal organisation to the original. The current height measurements of the rooms are identical to those described in the historical documents (3.21 $\mathrm{m}$ from floor to slab). The tower also maintains the dimensions mentioned in the documents (height of $8.5 \mathrm{~m}$ above ground level and an external diameter of $2.6 \mathrm{~m}$ ). A similar morphology of voids and carpentry is even detected in most of the openings (timber doors and windows, with half point arches and geometric decorations). In addition, it can also be established that the lamp and dome are the original ones from 1864.

From a constructive-architectural viewpoint, the lighthouse of Santa Clara Island is quite similar to other Spanish lighthouses of Typology B-2 (Figure 1). In particular, both in terms of its shape and its interior distribution, it is very similar to the lighthouses of Suances (Figure 9) and San Vicente de la Barquera (Figure 10), which are located in the nearby province of Cantabria. The lighthouse of Suances was planned on one single floor, with a hipped roof and a rectangular ground plan of $12.00 \times 8.50 \mathrm{~m}^{2}$. It had a similar structure to that of the lighthouse of Santa Clara Island, although in this case the interior stone wall was built parallel to the main facade.
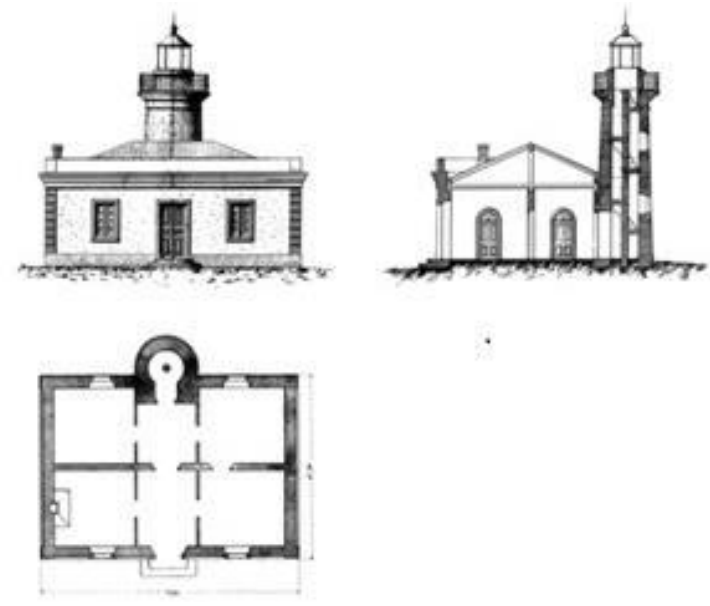

Figure 9. Drawings of the lighthouse of Suances 

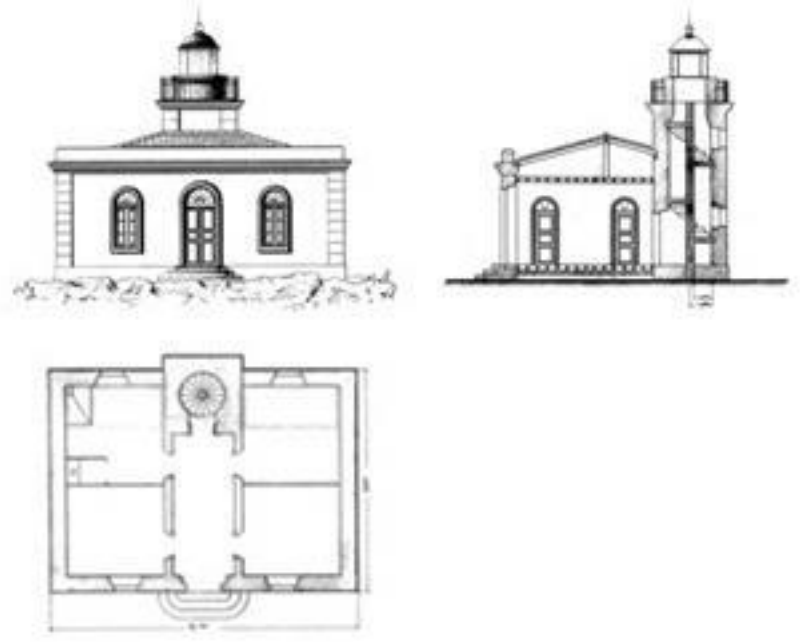

Figure 10. Drawings of the lighthouse of San Vicente de la Barquera

The lighthouse of San Vicente de la Barquera was also erected with a hipped roof and a rectangular ground of 11.70 $\mathrm{x} 8.65 \mathrm{~m} 2$. According to the original drawings, this building originally had doors and windows very similar to those of the lighthouse of Santa Clara Island. Unlike the two previous lighthouses, a square tower was erected in this building. This tower was raised almost completely embedded in the adjacent building.

Other similar buildings, although of greater size, are the lighthouses of Luarca, Avilés and Tazones, all located on the Cantabrian coast, in the north of Spain. In contrast to the three previous buildings, these lighthouses had adjacent buildings with six or eight rooms, thus improving the living and working conditions of the lighthouse keepers.

\section{CONCLUSIONS}

This work is a contribution towards understanding the historical lighthouses. It is expected that the results will contribute to highlight the heritage value of the architectural, structural and technological elements of the historical lighthouses, in order to be considered in future protection strategies.

The methodology was appropriate to determine the original construction system and architectonical elements of the lighthouse of Santa Clara Island. This building is quite similar to other Spanish lighthouses, such as the lighthouses of Suances, San Vicente de la Barquera, Luarca, Avilés or Tazones, which can be classified within the same typological group (Typology B-2).

The lighthouse of Santa Clara Island was built with walls of limestone masonry. Rectangular ashlars were used only in the corners and in the frames of the doors and windows. The building also had two interior stone walls, which supported the horizontal structure, as well as the roof posts. Originally, the building was topped by a hipped roof, sustained by a ridge beam and four hip rafters.

The structural elements of the tower (spiral staircase and stone walls), the lamp and the optics, except for the 1943 replacement, remain unchanged in time. This quality is associated with the tangible value of the lighthouse as pertaining to the Industrial Heritage. The original dome has also been maintained.
It has been possible to detect the original distribution of the house of the lighthouse keeper. The living quarters and the working place necessarily cohabited: the spatial distribution responded to a programme that was consciously executed. They formed part of another intangible symbol of the working culture of the construction era. The cistern, orchard and small pavilion for subsistence animals were necessary due to the confinement of the family during long periods. It was a combination of tangible and intangible values.

The viewpoints of the analysis conducted can be repeated for any other historical lighthouse. Only by performing an exhaustive analysis of the values of the lighthouse based on the tenets of the Industrial Heritage, is it possible to guide a restoration project of these magnificent constructions.

\section{ACKNOWLEDGMENT}

The authors wish to thank Ports of the State for the facilities provided to consult the historical documents of their private archive. In particular, they wish to highlight the support of Juan Francisco Rebollo Lledó, Head of the Service Area of Aid to Maritime Navigation of Ports of the State of Spain.

\section{REFERENCES}

[1] Rebollo, J.F. (2017). Lighthouses: 170th anniversary of the first maritime signalling plan in Spain (Los Faros: Referencias en el tiempo. 170 aniversario del primer plan de señalización marítima en España). X Congreso Nacional y II Congreso Internacional de Historia de la Construcción, San Sebastián, pp. 1-20.

[2] Sánchez-Beitia, S. (2017). The silent language of the light. The historical lighthouses of Spain (El lenguaje silencioso de la luz. Los faros históricos de España). Hispania Nostra, 26: 46-51.

[3] Stevenson, T. (1881). Lighthouse construction and illumination. E\&FN Spon, London and New York. http://doi.org/10.1017/CBO9780511795428

[4] Adams, W.H.D. (1870). Lighthouses and lightships: A descriptive and historical account of their mode of construction and organization. C. Scribner and Company, New York.

[5] Findlay, A.G. (1861). Description and list of the lighthouses of the world. Richard Holmes Laurie, London, 32-141.

[6] Fresnel, L. (1831). Memory of the stability of the lighthouse under construction of Belle-Ile (ocean) (Mémoire sur la stabilité du phare en construction à Belle-Ile (océan)). Annales des Ponts et Chaussées, Mémoires et documents, 1ère partie: 385-420. https://gallica.bnf.fr/ark:/12148/bpt6k408436j, accessed on Jan. 7, 2020.

[7] Gutiérrez Gracia, J (1926). Lighthouses and marine signals (Faros y señales marítimas). Imprenta F. Giménez, Madrid.

[8] Holland, F. R. (1988). America's Lighthouses: An Illustrated History. Courier Corporation, New York.

[9] Stevenson, A. (1857). On the theory and construction of lighthouses. Adam and Charles Black, Edinburgh. https://www.pharology.eu/resources/books/19)\%200n\% 20the $\% 20$ theory $\% 20$ and $\% 20$ construction $\% 20$ of $\% 20$ ligh thouses\%20(1857).pdf, accessed on Jan. 7, 2020. 
[10] Stevenson, D. (1864). Lighthouses. Lawrence scientific school, Eng. Dpt., Edinburgh.

[11] Soler, R. (2006). A century and a half of the Lighthouse Commission (Siglo y medio de la Comisión de Faros). Organismo Público de Puertos del Estado, Madrid.

[12] Sánchez-Beitia, S.; Luengas-Carreño, D.; Crespo de Antonio, M. (2019). Characterisation of historical lighthouses as Industrial Heritage elements. Application to the lighthouse of the Island of Santa Clara (Spain). WIT Transactions on The Built Environment, 191: 433442. http://doi.org/10.2495/STR190371

[13] Sánchez-Beitia, S. (2017). Catalogue of Spanish Lighthouses with Heritage Value (Catálogo de los faros con valor patrimonial de España). Ministerio de Educación, Cultura y Deporte, Instituto del Patrimonio Cultural de España: Madrid, 2017 http://www.culturaydeporte.gob.es/planesnacionales/planes-nacionales/patrimonioindustrial/actuaciones/catalogo-de-faros-con-valorpatrimonial-de-espana.html, accessed on Jan. 7, 2020.

[14] Sánchez-Beitia, S., Grzeszczyk, M., Luengas-Carreño, D., Crespo de Antonio, M. (2017). Identification and characteristics of the historical lighthouses of Spain (Identificación y características de los faros históricos de España). X Congreso Nacional y II Congreso Internacional de Historia de la Construcción, San Sebastián, pp. 21-36.

[15] Ministerio de Educación, Cultura y Deporte, Instituto del Patrimonio Cultural de España (2015). National Plan for Industrial Heritage. https://sede.educacion.gob.es/publiventa/d/20708C/19/0, accessed on May 21, 2019.

[16] Ministerio de Educación, Cultura y Deporte, Instituto del Patrimonio Cultural de España (2016). National Plan for Industrial Heritage, version 2016. www.culturaydeporte.gob.es/planesnacionales/dam/jcr:eba404cd-e170-419d-b46ae241ebd1b1b0/04-texto-2016-pnpi-plan-y-anexos.pdf, accessed on Jan. 7, 2020.

[17] Committee of Ministers, Council of Europe (1979).

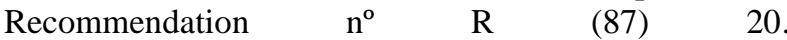
https://rm.coe.int/native/09000016804d434a, accessed on Jan. 7, 2020.
[18] Committee of Ministers, Council of Europe (1983). $\begin{array}{lllll}\text { Recommendation } & \mathrm{n}^{\mathrm{o}} & \mathrm{R} & \text { (90) }\end{array}$ https://rm.coe.int/CoERMPublicCommonSearchService s/DisplayDCTMContent?documentId=09000016804e1d 18, accessed on Jan. 7, 2020.

[19] ICOMOS - TICCIH (2003). The Nizhny Tagil Charter for the Industrial Heritage. https://www.icomos.org/18thapril/2006/nizhny-tagilcharter-e.pdf, accessed on Jan. 7, 2020.

[20] ICOMOS - TICCIH (2011). Principles for the conservation of industrial heritage sites, structures, areas and landscapes. https://ticcih.org/about/aboutticcih/dublin-principles/, accessed on Jan. 7, 2020.

[21] Council of Europe (2013). Industrial Heritage in Europe, Resolution 1924. www.assembly.coe.int/nw/xml/XRef/Xref-

XML2HTML-en.asp?fileid $=19512 \&$ lang $=E N$, accessed on Jan. 7, 2020.

[22] Dirección General del Ramo (1861). Memory of public works in the years 1859 and 1860 (Memoria de las obras públicas en los años 1859 y 1860). Imprenta Nacional, Madrid. https://biblioteca.juaneloturriano.com/Record/Xebook1 4110, accessed on Jan. 7, 2020.

[23] Consejo de Obras Públicas (1878). Public Works of Spain, Maritime lighting. Drawings of the lit lighthouses of the Spanish coast. Volume I, Lighthouses of the Ocean (Obras Públicas de España, Alumbrado marítimo. Planos de los faros encendidos de las costas de España). Tomo I, Faros del Océano, Madrid.

[24] Monterde, A. (1861). Lighthouse of Santa Clara Island (Faro de la Isla de Santa Clara). Revista de Obras Públicas, 12, tomo I (16):191-192.

[25] Cuerpo Nacional de Ingenieros de Caminos, Canales y Puertos (1878). Catalogue of objects concerning public works in Spain (Catálogo de los objetos referentes a obras públicas de España). Aribau y $\mathrm{C}^{\mathrm{a}}$, Madrid. http://bibliotecadigital.jcyl.es/es/catalogo_imagenes/gru po.cmd?path=10123889, accessed on Jan. 7, 2020.

[26] Monterde, A. (1883). Maritime lighting (Alumbrado marítimo). Revista de Obras Públicas, 31, tomo I (8): 113-124. 